\title{
Extractable Protein Levels in Latex Products and Their Associated Risks, Emphasizing American Dentistry
}

\author{
Katrina Cornish $^{1 *}$, Griffin M. Bates ${ }^{1}$, J. Lauren Slutzky ${ }^{1}$, Anatoliy Meleshchuk ${ }^{1}$, Wenshuang Xie ${ }^{1}$, Krysta \\ Sellers ${ }^{2}$, Richard Mathias ${ }^{2}$, Marissa Boyd ${ }^{3}$, Rochelle Castaneda ${ }^{3}$, Michael Wright ${ }^{4}$ and Lise Borel ${ }^{5}$
}

${ }^{1}$ Department of Food, Agricultural and Biological Engineering, The Ohio State University, 1680 Madison Avenue, Wooster, OH 44691, USA; ${ }^{2}$ A.T. Still University Arizona School of Dentistry and Oral Health, 5850 E. Still Circle, Mesa, AZ 85206, USA; ${ }^{3}$ Yulex Corporation, 37860 West Smith-Enke Road, Maricopa, AZ 85138, USA; ${ }^{4}$ Williamson Medical Center, Franklin, TN, USA; 5MIRUS3, West Chester, PA, USA

\begin{abstract}
Background: Over $8 \%$ of the US population have detectable Type I Hevea latex IgE antibodies and, upon exposure to natural latex and rubber products, are at risk for potentially dangerous reactions, especially in dental settings where these products are exposed to mucosal membranes.

Methods: Extractable antigenic protein levels were quantified in dental dams, examination gloves, and various other dental and rubber products. ASTM standards D6499 (antigenic protein) and D5712 (total protein) were used to quantify the protein content.

Results: In dental dams, extractable protein content ranged from $<3$ to $130-200 \mu \mathrm{g} / \mathrm{dm}^{2}$, which are generally accepted by regulatory bodies to be low/nonsensitizing levels and high/potentially sensitizing levels, respectively. In addition, although examination gloves from Malaysian glove manufacturers consistently exhibited a lower extractable protein content $\left(<9 \mu \mathrm{g} / \mathrm{dm}^{2}\right)$ than gloves from Thai manufacturers $\left(16-23 \mu \mathrm{g} / \mathrm{dm}^{2}\right)$, these levels are both below the $50 \mu \mathrm{g}$ protein/g latex film threshold accepted by FDA and used by manufactures. There was no correlation between extractable protein content and the price or thickness of dental dams or examination gloves. Most of the other assorted dental products tested displayed low extractable protein content $\left(<2.5 \mu \mathrm{g} / \mathrm{dm}^{2}\right)$. Nearly all dental products made from natural rubber contained detectable antigenic Hevea proteins, subjecting previously sensitized patients and providers to risk of severe allergic reaction. A case study describes a female patient, with no previous history of Type I latex allergy, reacted severely to a dental dam mouth exposure, necessitating her admission to the intensive care unit (ICU) of a local hospital for management of respiratory failure, with discharge after 4 days.

Conclusions: It is clear that some dental products may pose a significant risk of Type I latex protein allergy sensitization, due to repeated contact, and that a single exposure can induce a severe reaction in a previously sensitized person, even when no prior latex allergy history is known.
\end{abstract}

Keywords: Latex allergy; Extractable protein; Product safety; Case report

\section{INTRODUCTION}

Many commercial medical products are made with natural rubber harvested from the Brazilian rubber tree (Hevea brasiliensis, Müll, Arg.). Utilized for its combination of strength, flexibility, and hydrophobicity, natural rubber provides both patient comfort and protection against the transmission of blood-borne pathogens [1]. Unfortunately, natural rubber and latex products made from
Hevea possess allergenic proteins in varying combinations and amounts. High protein levels in products not leached during their manufacture have led to the sensitization of a significant proportion of the population with life-threatening Type I latex allergy [2-11]. The instigators of this sensitization, soluble Hevea proteins, are found in Hevea natural rubber latex, a cytoplasm (lacking nuclei and mitochondrion) containing many constituents, most notably rubber particles and three general categories of

Correspondence to: Katrina Cornish, Department of Food, Agricultural and Biological Engineering, The Ohio State University, 1680 Madison Avenue, Wooster, OH 44691, USA, Tel: (330)263-3982; E-mail: cornish.19@osu.edu

Received: October 23, 2018, Accepted: February 11, 2019, Published: February 18, 2019

Citation: Cornish K, Bates GM, Slutzky JL, Meleshchuk A, Xie W, Sellers K, et al. Extractable Protein Levels in Latex Products, and Their Associated Risks, Emphasizing American Dentistry, Biol Med (Aligarh) 11:456. doi:10.35248/0974-8369.19.11.456.

Copyright: $\odot 2019$ Cornish K, et al. This is an open-access article distributed under the terms of the Creative Commons Attribution License, which permits unrestricted use, distribution, and reproduction in any medium, provided the original author and source are credited. 
proteins: hydrophilic (water-soluble) proteins $(\sim 50 \%$ of total protein content), rubber particle bound proteins $(\sim 25 \%)$, and other hydrophobic proteins ( $\sim 25 \%$ ) [12]. Liquid latex (a rubber particle emulsion) is used to manufacture dipped products such as medical gloves and dental dams, while other products, such as stoppers and tires, are made from solid rubber (made by coagulating and drying liquid latex). Products from each method of manufacture contain all three groups of proteins.

Type I latex allergy, caused by exposure to Hevea latex proteins, remains a major public health problem in the United States and throughout the world. Hevea-specific IgE antibodies are detectable in over $8 \%$ of the general US population ( $~ 30$ million Americans), although many of these people do not yet present clinical symptoms of latex allergy [4,7]. Few, if any, Americans exhibited Type I latex allergy before the 1980s AIDS epidemic, when the CDC required glove use for any direct patient contact. This had the effect of an immediate 30-fold increase in latex glove demand, with ever-increasing demand following [8-10]. To meet this exponential increase in demand, some new and existing manufacturers truncated the fabrication process, eliminating the in-line washing/leaching steps, thereby producing products with far higher protein levels than previously seen. Exposure to these highly allergenic items resulted in an unprecedented and massive surge in the number of healthcare workers and patients with Type I latex allergy [8-10]. Inhalation of aerosolized, protein-bearing corn starch glove powder, as well as direct contact with mucosal membranes and body fluids of patients with latex products during medical and dental procedures, were major contributors to worker and patient sensitization [10].

Various methods to reduce allergenic protein levels in latex have been used, including multiple types of deproteinization and double centrifugation [13-15]. However, although protein precipitation and double centrifugation methods reduce the total protein load in Hevea latex products, making them less sensitizing, it is impossible to eradicate all proteins from natural rubber products. So-called “deproteinized natural rubber (DPNR)" lattices have been treated with proteases and peptidases-enzyme that partially breaks up the latex proteins, but have more protein than the untreated lattices; nearly all the protein has become the soluble type similar to that which caused Type I latex allergy, originally.

Today, most manufacturers use effective, inline leaching during latex product fabrication, and the Food and Drug Administration recently (January 18, 2017) banned powdered medical gloves that eliminates the issue of exposure from aerosolization. In this final rule, FDA banned (1) powdered surgeon's gloves (21 CFR 878.4460), (2) powdered patient examination gloves (21 CFR 880.6250), and (3) absorbable powder for lubricating a surgeon's gloves (21 CFR 878.4480). Properly leached products pose a low risk of sensitization, but it is impossible to determine the protein content by the physical appearance of a product $[16,17]$. Of course, even well-leached, low-protein, latex products still pose a risk of triggering a serious reaction to any patient who has already been sensitized with Type I latex allergy: the protein dose to sensitize a person is often far greater than the dose required to trigger a systemic reaction, or even an anaphylactic reaction, in a sensitized individual [1].

Dental patients are particularly at risk due to the frequency of procedures utilizing latex products, the unfortunate suitability of saliva as a protein extraction medium, and the inability to predict when a sensitization threshold is crossed resulting in a Type I, possibly life-threatening, allergic reaction to the next latex protein exposure [1].

Previous researchers quantified extractable protein in certain products and have found that toy balloons and dental dams are a significant source of latex exposure [11,18-21]. This research focuses on products typically used in dentistry to determine product extractable protein levels, and the relationship between extractable latex protein content and product type, cost, and manufacturing location.

\section{MATERIALS AND METHODS}

An assortment of rubber materials and products used in dental practices were procured in 2009 and 2011. Extractable protein was quantified using the immunochemical ELISA testing method described in ASTM standard D 6499-03 (Standard test method for the immunological measurement of antigenic protein in natural rubber and its products). ASTM standard D 6499-03 was modified to more accurately quantify low protein content by diluting the standard curve down from 2 to $0.2 \mathrm{mg} / \mathrm{mL}$. This method is referred to as the trace protein method in this paper. Hevea latex was established as a positive control, while nitrile (a synthetic latex) and guayule latex (an alternative natural rubber) [22] were utilized as negative controls. Furthermore, once dental dams from Patterson Dental were proven to contain high amounts of soluble protein, this brand was included as a positive control in subsequent assays. For all data reported in this paper, carefully matched background optical densities were subtracted from raw spectrometric data.

For particular samples, extractable protein, presented as total protein, was quantified using the test method prescribed by ASTM D5712 (Standard test method for the analysis of aqueous extractable protein in natural rubber and its products using the modified Lowry method). The total protein in liquid latex samples was quantified using the method described in ASTM D107606, Category 4 (Standard specification for rubber-concentrated, ammonia-preserved, creamed, and centrifuged natural latex).

\section{RESULTS}

\section{Dental dams}

Extractable protein content was quantified in 17 different samples of unframed, powdered dental dams (Table 1), Malaysia being the predominant country of manufacture, excepting one each from Sweden and the United States. Using the threshold values of 50 $\mu \mathrm{g} / \mathrm{g}$ and $200 \mu \mathrm{g} / \mathrm{dm}^{2}$ established as nonsensitizing protein dose levels, seven dental dam samples, from three companies, had significantly high extractable protein contents [22]. An additional seven dental dam samples, from five companies, contained low extractable protein levels. Unexpectedly, there was no correlation between the extractable protein content and the price of a dental dam (Figure 1, $\mathrm{r}^{2}=0.215$ ). Additionally, the thickness of the dam was not correlated to extractable protein content (Figure 2; $\mathrm{r}^{2}=0.065$ ). With the exception of one powdered dental dam manufactured in Germany, with relatively high extractable protein content, framed dental dams consistently had low extractable protein levels $(<3 \mu \mathrm{g} /$ $\mathrm{dm}^{2}$; Table 2). Framed dental dams are devices in which the dam 
Table 1: Extractable protein in unframed, powdered, natural rubber latex dental dams determined by immunochemical ELISA. All unframed dams were manufactured in Malaysia (except Ivory natural scent; Sweden). Prices are as of July 2009. The guayule natural rubber is not currently commercially available. Extractable proteins from Hevea dams were quantified by ASTM D6499, whereas guayule dams proteins were quantified using a guayule-specific immunochemical ELISA (Kostyal et al., ILC, 2011). ASTM D6499 does not detect guayule proteins.

\begin{tabular}{|c|c|c|c|c|c|c|}
\hline Manufacturer & Color/Weight & Scent & Price $(\$ /$ dam $)$ & Protein $\left(\mu \mathrm{g} / \mathrm{dm}^{2}\right)$ & Protein $(\mu \mathrm{g} / \mathrm{g})$ & Thickness (mm) \\
\hline Coltene/Whaledent & Fiesta/heavy & Natural & 0.58 & 49 & 42 & 0.25 \\
\hline Coltene/Whaledent & Fiesta/thin & Natural & 0.48 & 86.8 & 119.8 & 0.15 \\
\hline Coltene/Whaledent & Dark & Natural & 0.36 & 153.1 & 143.5 & 0.18 \\
\hline Crosstex & Blue & Natural & 0.19 & 2.57 & 3.56 & 0.16 \\
\hline Henry Schein & Green & Natural & 0.24 & 2.03 & 2.03 & 0.21 \\
\hline Hygenic & Natural & Natural & 0.33 & 131.9 & 205.8 & 0.14 \\
\hline Ivory & Green & Natural & 0.28 & 0.64 & 0.69 & 0.21 \\
\hline Ivory & Green & Mint & 0.28 & 7.22 & 8.57 & 0.17 \\
\hline Patterson Dental & Dark/medium & Natural & 0.36 & 155.7 & 173.4 & 0.19 \\
\hline Patterson Dental & Natural/medium & Natural & 0.36 & 166.1 & 195.3 & 0.2 \\
\hline Patterson Dental & Thin green & Natural & 0.34 & 170 & 214.3 & 0.16 \\
\hline Patterson Dental & Medium green & Natural & 0.36 & 188.6 & 216.3 & 0.18 \\
\hline Patterson Dental & Green/heavy & Natural & 0.36 & 198.5 & 215.9 & 0.25 \\
\hline Safetouch & Blue & Natural & 0.25 & 1.37 & 2.01 & 0.13 \\
\hline Safetouch & Thin green & Mint & 0.25 & 1.71 & 2.71 & 0.13 \\
\hline SS White & Green & Mint & 0.19 & 2.63 & 3.69 & 0.16 \\
\hline Guayule & Natural & Natural & - & $0.066^{*}$ & $0.075^{*}$ & 0.4 \\
\hline
\end{tabular}

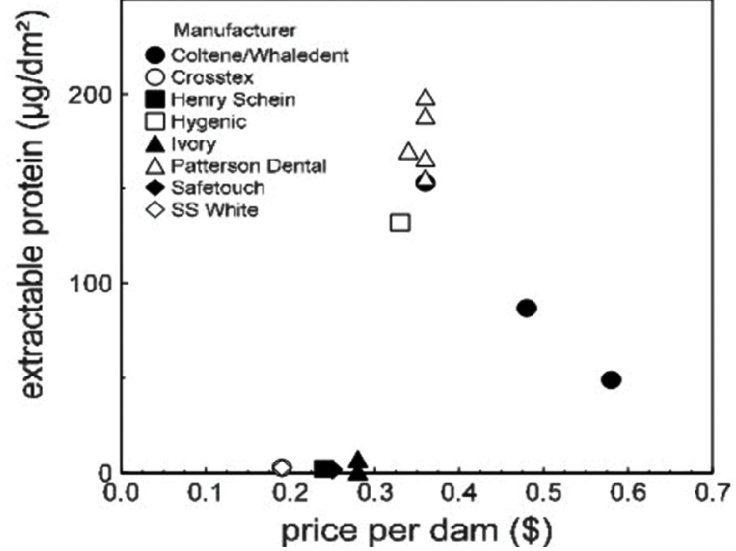

Figure 1: Relationship between unit price and extractable protein content of powdered natural rubber latex dental dams.



Figure 2: Relationship between thickness of dental dams and extractable protein content in dental dams.

Table 2: Extractable protein in framed dental dams. Protein values were determined by immunochemical testing using the trace protein method instead of the standard method in ASTM D6499. The Aseptico/Advena natural rubber dam claims to be made from a special process that minimizes allergens (NR latex, vanilla scented). Both natural and synthetic framed dams by Loser and Co/Zirc Co are antimicrobial. Prices determined July 2009.

\begin{tabular}{|c|c|c|c|c|c|c|c|c|}
\hline Manufacturer & Material & $\begin{array}{l}\text { Country of } \\
\text { Mfr }\end{array}$ & Color & Powder & $\begin{array}{c}\text { Price }(\$ / \\
\text { dam) }\end{array}$ & $\begin{array}{l}\text { Protein }(\mu \mathrm{g} / \\
\left.\mathrm{dm}^{2}\right)\end{array}$ & Protein $(\mu \mathrm{g} / \mathrm{g})$ & $\begin{array}{l}\text { Thickness } \\
\text { (mm) }\end{array}$ \\
\hline Aseptico/Advena & NR latex & Unknown & Blue & Y & 1.3 & 2.57 & 2.75 & 0.21 \\
\hline Ivoclar Vivadent & NR latex & Malaysia & Blue & Y & 1.45 & 2.74 & 2.51 & 0.28 \\
\hline Loser and Co./ Zirc Co. & NR latex & Germany & Natural & Y & 1.9 & 64.25 & 54.87 & 0.27 \\
\hline Aseptico/ Advena & $\begin{array}{l}\text { Synthetic } \\
\text { rubber }\end{array}$ & Unknown & Mauve & $\mathrm{N}$ & 2.6 & $0.27^{*}$ & $0.25^{*}$ & 0.23 \\
\hline Hygenic & $\begin{array}{l}\text { Synthetic } \\
\text { rubber }\end{array}$ & USA & Purple & $\mathrm{N}$ & 2.23 & $2.27 / 0.17^{*}$ & $1.51 / 0.09^{*}$ & 0.45 \\
\hline Hygenic & Nitrile & USA & Purple & $\mathrm{N}$ & 1 & $0.35^{*}$ & $0.17^{*}$ & 0.52 \\
\hline Loser and Co./ Zirc Co. & $\begin{array}{l}\text { Synthetic } \\
\text { rubber }\end{array}$ & USA & Blue & $\mathrm{N}$ & 2.1 & $0.25^{*}$ & $0.3^{*}$ & 0.25 \\
\hline
\end{tabular}


is prefitted to a skeleton that fits close to the patient's face and allows the dental dam film to be positioned to isolate the targeted dental area, while also permitting access to the mouth for suction, or other devices, without having to remove and replace the dam during the procedure.

\section{Dental examination gloves}

Extractable protein levels in 26 examination glove samples (from 10 brands), including vinyl, nitrile, and guayule gloves as controls, were examined (Table 3). Examination gloves manufactured in Malaysia presented low extractable protein contents $\left(<9 \mu \mathrm{g} / \mathrm{dm}^{2}\right.$ and $<11.6 \mu \mathrm{g} / \mathrm{g}$ ). Thai manufactured gloves (Plak Smacker brand) contained higher extractable protein levels $\left(16-23 \mu \mathrm{g} / \mathrm{dm}^{2}\right)$ but were well below the sensitization threshold levels of $200 \mu \mathrm{g} / \mathrm{dm}^{2}$ and $50 \mu \mathrm{g} / \mathrm{g}$. Consistent with the results from dental dam testing, extractable protein content was not correlated with the cost of gloves.

\section{Miscellaneous dental products}

A variety of nonglove or dental dam rubber products were tested. Cure light barriers, dam clamp cushions, dental tape, finger cots, multiuse latex barriers, prophy angles, and wedjets had very low extractable protein levels $\left(<7.90 \mu \mathrm{g} / \mathrm{dm}^{2}\right.$ and $<7.95 \mu \mathrm{g} / \mathrm{g}$, Table 4). Isolator and protective devices and t-bar light barriers had somewhat higher extractable protein levels but only one product, and the Magic Clamp isolator and protector had a protein content over the $50 \mu \mathrm{g} / \mathrm{g}$ threshold. The children's toys examined, both the balloons and the finger puppets, had low levels of extractable protein, (7.09 and $1.44 \mu \mathrm{g} / \mathrm{dm}^{2}$, respectively; Table 4). However, previous research has shown that, similar to dental dams (Figure 1, Table 1), latex balloon extractable protein content is highly dependent on manufacturer [10].

\section{Alternative product materials}

Alternative elastomeric materials have been developed to circumvent the risk of Type I latex allergy in patients, including guayule latex, and protease-treated latex (DPNR) [13-15,22]. Examples of DPNR gloves are the sample tested from Tillotson (Table 3). Using both the D5712 (total extractable protein) and the D6499 (antigenic extractable protein) quantification methods, Tillotson gloves were compared to latex film samples with high (Patterson Dental) and low protein content (Ivory) dental dams. However, Tillotson glove samples gave different results for the two methods (Figure 3). Tillotson gloves displayed significantly high

Table 3: Extractable protein in examination gloves. Protein values* determined by immunochemical testing using trace protein method instead of standard method in ASTM D6499.

\begin{tabular}{|c|c|c|c|c|c|c|c|c|c|}
\hline $\mathrm{Mfr}$ & Material & $\begin{array}{c}\text { Country of } \\
\mathrm{Mfr}\end{array}$ & Color & Scent & Powder & Size & Price $(\$ / 100)$ & $\begin{array}{l}\text { Protein }(\mu \mathrm{g} / \\
\left.\mathrm{dm}^{2}\right)\end{array}$ & $\begin{array}{c}\text { Protein } \\
(\mu \mathrm{g} / \mathrm{g})\end{array}$ \\
\hline Adenna & Latex & Unknown & Black & Natural & $\mathrm{N}$ & $\mathrm{XL}$ & 7.74 & 1.33 & 1.83 \\
\hline AmerCare Inc. & Latex & Malaysia & Black & Natural & $\mathrm{N}$ & M & 5.99 & 1.24 & 1.86 \\
\hline AmerCare Inc. & Latex & Malaysia & Blue & Natural & $\mathrm{N}$ & M & 15.98 & 3.13 & 2.31 \\
\hline AmerCare Inc. & Latex & Malaysia & Natural & Natural & $\mathrm{N}$ & M & 4.59 & 1.75 & 3.27 \\
\hline AmerCare Inc. & Latex & Malaysia & Natural & Natural & Y & M & 3.79 & 5.34 & 8.28 \\
\hline Cypress & Latex & Unknown & Natural & Natural & $\mathrm{N}$ & $\mathrm{XL}$ & 6 & 1.21 & 2.08 \\
\hline Evolution One & Latex & Malaysia & Natural & Natural & $\mathrm{N}$ & M & 11.9 & 4.41 & 6.14 \\
\hline Glove Nation & Latex & Malaysia & Black & Natural & Y & M & 5.99 & 0.59 & 0.85 \\
\hline Glove Nation & Latex & Malaysia & Natural & Natural & $\mathrm{N}$ & $\mathrm{M}$ & 4.59 & 0.41 & 0.61 \\
\hline Glove Nation & Latex & Malaysia & Natural & Natural & Y & M & 3.79 & 6.9 & 8.48 \\
\hline Glove Nation & Latex & Malaysia & Blue & Natural & $\mathrm{N}$ & M & 15.98 & 0.85 & 0.5 \\
\hline High Five & Latex & China & Natural & Natural & $\mathrm{N}$ & M & 8.26 & 0.08 & 0.4 \\
\hline High Five & Latex & Malaysia & Blue & Natural & $\mathrm{N}$ & M & 7.5 & 0.14 & 0.68 \\
\hline Plak Smacker & Latex & Malaysia & Natural & Natural & $\mathrm{Y}$ & M & 3.99 & 8.6 & 11.54 \\
\hline Plak Smacker & Latex & Thailand & Natural & Bubblegum & $\mathrm{N}$ & M & 7.65 & 16.53 & 26.34 \\
\hline Plak Smacker & Latex & Thailand & Natural & Natural & $\mathrm{N}$ & M & 4.99 & 22.97 & 37.33 \\
\hline Plak Smacker Blossom & Latex & Unknown & Blue & Natural & $\mathrm{N}$ & $\mathrm{S}$ & 8.5 & 4.24 & 6.09 \\
\hline Superior & Latex & Malaysia & Natural & Natural & $\mathrm{Y}$ & M & nd & 0.72 & 1.01 \\
\hline Tillotson & Latex & Malaysia & Natural & Natural & $\begin{array}{l}\mathrm{N}, \text { polymer- } \\
\text { lined }\end{array}$ & $\mathrm{L} / \mathrm{XL}$ & 9.81 & 0.18 & 0.87 \\
\hline Tillotson & Latex & Malaysia & Natural & Natural & $\begin{array}{l}\mathrm{N}, \text { polytex- } \\
\text { lined }\end{array}$ & $\mathrm{L}$ & 14.03 & $0.05 / 3.02^{*}$ & $0.24 / 4.37^{*}$ \\
\hline Dynarex & Nitrile & Malaysia & Blue & Natural & $\mathrm{N}$ & M & 8.64 & $0.69^{*}$ & $1.76^{*}$ \\
\hline Dynarex & Vinyl & China & Natural & Natural & $\mathrm{N}$ & M & 5.61 & $0.68^{*}$ & $1.34^{*}$ \\
\hline High Five & Nitrile & China & Blue & Natural & $\mathrm{N}$ & M & nd & $4.36^{*}$ & $7.99^{*}$ \\
\hline King Seal & Synthetic & $\begin{array}{l}\text { Malaysia/ } \\
\text { Indonesia }\end{array}$ & Natural & Natural & $\mathrm{N}$ & M & nd & $0.57^{*}$ & $0.8^{*}$ \\
\hline Plak Smacker Blossom & Nitrile & Unknown & Green & Natural & $\mathrm{N}$ & M & nd & $0.21^{*}$ & $0.34^{*}$ \\
\hline Guayule & Guayule & USA & Natural & Natural & $\mathrm{N}$ & . & . & $1.12^{*}$ & $0.8^{*}$ \\
\hline
\end{tabular}


Table 4: Extractable protein in miscellaneous dental products (nonpowdered). Protein values* determined by immunochemical testing using trace protein method instead of standard method in ASTM D6499.

\begin{tabular}{|c|c|c|c|c|c|c|}
\hline Manufacturer & Product & Material & Country of Manufacturer & Color & Protein $\left(\mu \mathrm{g} / \mathrm{dm}^{2}\right)$ & Protein $(\mu g / g)$ \\
\hline Hygenic & Wedjets & Latex & USA & Yellow & 1.39 & 0.4 \\
\hline Grafco & Finger cot & Latex & China & Natural & 2.13 & 1.71 \\
\hline Magic Clamp & Isolator and protector & Latex & Unknown & Green & 62.39 & 78.98 \\
\hline Steri-shield & Multi-use latex barrier & Latex & Malaysia & Blue & 7.9 & 7.95 \\
\hline Steri-shield & Cure light barrier & Latex & Malaysia & Natural & 2.26 & 2.04 \\
\hline Steri-shield & t-bar light barrier & Latex & Malaysia & Blue & 20.48 & 21.34 \\
\hline Cushee & Dam clamp cushion & Rubber & Canada & Blue/yellow & $1.03^{*}$ & $0.16^{*}$ \\
\hline Danville & Dental tape & & Unknown & White w print & $0.17^{*}$ & $0.52 *$ \\
\hline Dental Resources & Prophy angle & Synthetic & USA & Grey & $11.34^{*}$ & $0.23^{*}$ \\
\hline Hygenic & Wedjets & Synthetic & USA & Green & 0.21 & 0.09 \\
\hline Magic Clamp & Isolator and protector & Synthetic & Unknown & Blue & $10.18^{*}$ & $2.14^{*}$ \\
\hline Pioneer & Balloon & Latex & USA & White w print & 7.09 & 4.6 \\
\hline Unknown & Finger puppet & Unknown & Unknown & Black, white & $1.44^{*}$ & $0.29 *$ \\
\hline
\end{tabular}

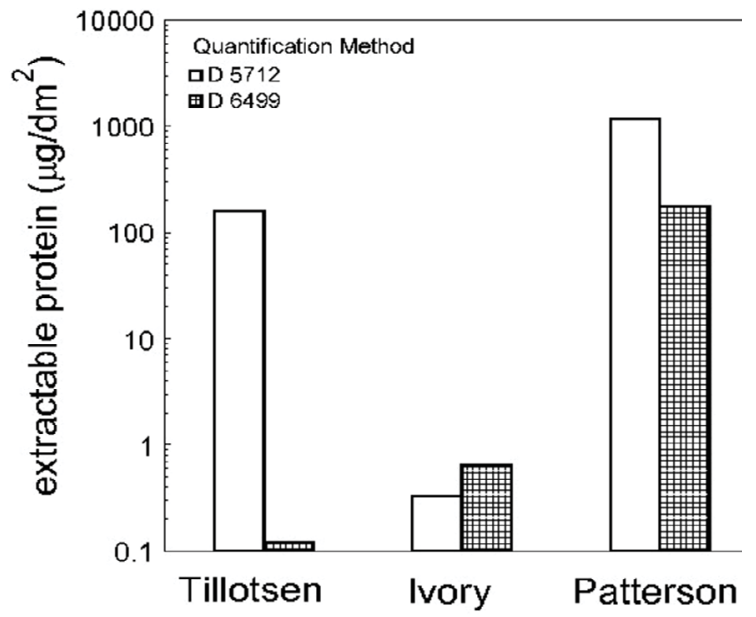

Figure 3: Comparison of two protein quantification methods and apparent protein amounts extracted from three different products (mean of three determinations).

levels of total extractable protein, which makes the marketing term "deproteinized" misleading. Although the protease treatment did not remove the protein and actually increased total extractable protein, it did disrupt most of the pre-existing epitopes associated with the current form of Type I latex allergy.

\section{CASE REPORT}

A 62-year-old woman presented to a local dentist office in need of an uncomplicated restoration. The patient had a limited medical history and self-reported no prior reaction to latex. In preparation for her procedure, a dam was placed in the mouth to check for fit, and then promptly removed. Within $10 \mathrm{~min}$ of dam exposure, the patient started to complain of a tingling sensation around her lips. She was re-examined by a dentist within $5 \mathrm{~min}$ of the initial complaint of lip tingling. Substantial swelling of the lips and tongue were noted, and emergency services (EMS) were contacted. Upon EMS arrival (20 min after initial symptoms developed), the patient was given $50 \mathrm{mg}$ intravenous diphenhydramine, $0.3 \mathrm{mg}$ intramuscular epinephrine, and $20 \mathrm{mg}$ intravenous famotidine. She was subsequently intubated in the emergency room and admitted to the intensive care unit (ICU) for management of respiratory failure.
The patient required mechanical ventilation and was given dexamethasone $10 \mathrm{mg}$ every $6 \mathrm{~h}$, diphenhydramine $50 \mathrm{mg}$ every $6 \mathrm{~h}$, and famotidine $20 \mathrm{mg}$ every $12 \mathrm{~h}$. A substantial reduction in airway edema was noted at $72 \mathrm{~h}$, as evinced by physical exam and endotracheal tube cuff leak. At this time, the patient was extubated and transferred to a standard care medical floor. She was discharged $24 \mathrm{~h}$ later on hospital day four.

Serum Hevea-specific IgE antibodies were collected upon ICU admission. Analysis was conducted via ImmunoCAP autoanalyzer and revealed a negative result (lower limit of detection $=0.24$ $\mathrm{mg} / \mathrm{mL}$ ). The ImmunoCAP has an approximate sensitivity and specificity of $70 \%$ and $95 \%$, respectively [23,24]. Considering the limited sensitivity of $\operatorname{IgE}$ analysis, it is reasonable to assume the patient reacted to Hevea proteins in the dental dam based on the clinical presentation. The patient was counselled on using extreme caution in situations where a repeat latex exposure is likely, and referred to an allergy specialist on discharge. Ultimately, the patient did not seek any further care and was lost to follow up.

\section{DISCUSSION}

Most of the latex products that we tested, used in American dental practice, do not have extractable protein levels greater than the $200 \mu \mathrm{g} / \mathrm{dm}^{2}$ and $50 \mu \mathrm{g} / \mathrm{g}$ protein thresholds set by the FDA. These products are not likely to present a dose sufficient to sensitize most people [1]. Among all the products tested, only a subset of dental dams have sufficiently high levels of extractable latex proteins to pose a significant risk of patient sensitization to Hevea latex proteins [1]. Such exposure may lead to new cases of Type I latex allergy. Although it was logical to assume that inexpensive dental dams would exhibit the highest extractable protein content, there was no correlation between cost of dam and protein content (Figure 1), and the lowest cost dental dams actually had the lowest extractable protein contents. Malaysian dental dam manufacturing plants broadly either produced low protein or high protein dental dams, and so we investigated if the high protein dams retained more protein than low protein dams due to product thickness. Our research demonstrated that film thickness was not correlated with extractable protein content. Unfortunately, apart from the data set provided by this study, there is no way to reliably determine whether a dental dam has a high extractable protein content 
from brand name, appearance, price, or country of manufacture. However, dental dams purchased two years apart were found to have consistent protein levels. For example, Patterson Dental and Hygenic brand dental dams remained at high protein levels $(>140$ $\left.\mu \mathrm{g} / \mathrm{dm}^{2}\right)$ while CrossTex dental dams retained low levels $(5.15 \mu \mathrm{g} /$ $\mathrm{dm}^{2}$ ). The current protein testing methods (ASTM methods D571203, D6499-07 and D7247-08) are designed specifically to evaluate natural rubber products made from Hevea latex. Identifying high protein materials and promoting safer products is greatly enhanced through the vigorous utilization of these testing procedures $[10,22]$. Yet, these methods are intended for manufacturers and are technologically and resource dependent providing a barrier for most users. Therefore, without product protein content data, the only safe course of action for dental providers is to assume that natural rubber dental dams pose a significant sensitization and reaction risk to patients. Rinsing high protein dams in water does not significantly decrease extractable protein content (data not shown) and special extraction media must be used (Cornish, unpublished data). From the case study reported in this paper, it is very clear that dental dams especially high protein ones, pose a significant risk to dental patients, even though the brand of dental dam was not ascertained.

Other dental products contained lower protein levels than the highest protein dental dams, with cost, again, not being a correlating factor. Among the examination gloves studied, the two highest extractable protein content brands were on the lower end of costs per pair, but other similarly low-priced gloves had low protein levels.

When it comes to DPNR materials, these materials display antigen content below the sensitization threshold [1]. This would not protect previously sensitized patients from allergic reactions, but it would mean that patients would be afforded some protection due to delayed sensitivity. However, the sensitization potential of these new epitopes has yet to be evaluated in humans, and the soluble protein levels are greater than those that caused Type I latex allergy. Thus, products made from DPNR lattices should always be thoroughly leached (washed) during their manufacture to reduce the protein exposure to as low as can be achieved.

\section{CONCLUSION}

Most commercial dental products contain very little extractable protein, but a subset of dental dams have sufficiently high levels of soluble latex protein to pose a significant risk of Type I latex allergy reaction and sensitization. There is currently no method developed to determine the products that do or do not contain high levels of protein through rapid visual, physical, or chemical testing. Therefore, all dental dams, unless specifically labeled otherwise, must be treated as though they have high extractable protein content. Furthermore, nearly all natural rubber dental products contain detectable Hevea antigenic proteins, and have the potential to induce dangerous Type I allergic reactions in patients previously sensitized to latex proteins. For this group of patients, dental providers can only safely use products made from guayule natural rubber latex or synthetic elastomers, none of which harbor Hevea antigenic latex proteins.

\section{ACKNOWLEDGMENTS}

This work was supported by the Ohio State University and by
Yulex Corporation. The authors thank Tom Marsh, President, Centrotrade Minerals \& Metals, Inc. for his generous gift of Hevea latex.

\section{REFERENCES}

1. Cornish K. Assessment of the risk of Type I latex allergy sensitization or reaction during use of products made from latex derived from guayule and other alternate rubber-producing species. Rubber Sci. 2012;25(2):139-155.

2. Cornish K, Lytle CD. Viral impermeability of hypoallergenic, low protein, guayule latex films. J Biomed Mater Res. 1999;47(3):434-437.

3. Charous BL, Hamilton RG, Yunginger JW. Occupational latex exposure: characteristics of contact and systemic reactions in 47 workers. J Allergy Clin Immunol. 1994;94(1):12-18.

4. Grzybowski M, Ownby DR, Peyser PA, Johnson CC, Schork MA. The prevalence of anti-latex $\operatorname{IgE}$ antibodies among registered nurses. J Allergy Clin Immunol. 1996;98(3):535-544.

5. Grzybowski M, Ownby DR, Rivers EP, Ander D, Nowak RM. The prevalence of latex-specific IgE in patients presenting to an urban emergency department. Ann Emerg Med. 2002;40(4):411-419.

6. Larsen LE. Latex allergy: how a protective material threatens some of its users. Lab Med. 1998;29(5):278-285.

7. Ownby DR, Ownby HE, McCullough JA, Shafer AW. The prevalence of anti-latex IgE antibodies in 1000 volunteer blood donors. J Allergy Clin Immunol. 1996;97(6):1188-1192.

8. Slater JE. Rubber anaphylaxis. N Engl J Med. 1989;320(17):11261130.

9. Sussman GL, Beezhold DH, Liss G. Latex allergy: historical perspective. Methods. 2002;27(1):3-9.

10. Tomazic VJ, Withrow TJ, Fisher BR, Dillard SF. Latex-associated allergies and anaphylactic reactions. Clin Immunol Immunopathol. 1992;64(2):89-97.

11. Kostyal D, Horton K, Beezhold D, Lockwood S, Hamilton RG. Latex as a significant source of Hevea brasiliensis allergen exposure. Ann Asthma Allergy Immunol. 2009;103(4):354-355.

12. Jacob JL, d'Auzac J, Prevôt JC. The composition of natural latex from Hevea brasiliensis. Clin Rev Allergy. 1993;11(3):325-337.

13. Honeycutt T, Doyle W, Clarke M, Culp R, Swanson M. Yytex NRL: the science behind ultra-low protein natural rubber latex. Rubber World. 2007;237(2):32-36.

14. Trautman JC. Method of neutralizing protein allergens in natural rubber latex product formed thereby. US Patent 5,777,004. 1998.

15. Perrella FW, Pieroni JK, Tillotson TN. Enzyme, stabilizer and antioxidant treated natural rubber latex product and method of processing same. US Patent 6,380,283. 2002.

16. Crippa M, Belleri L, Mistrello G, Tedoldi C, Alessio L. Prevention of latex allergy among health care workers and in the general population: latex protein content in devices commonly used in hospitals and general practice. Int Arch Occup Environ Health. 2006;79(7):550-557.

17. Hamilton RG, Brown RH. Impact of personal avoidance practice on healthcare workers sensitized to natural rubber latex. J Allergy Clin Immunol. 2000;105(4):839-841.

18. Palosuo T, Alenius H, Turjanmaa K. Quantitation of latex allergens. 
Methods. 2002;27(1):52-58

19. Jones RT, Scheppmann DL, Heilman DK, Yunginger JW. Prospective studies of extractable latex allergen contents of disposable medical gloves. Ann Allergy. 1994;73(4):321-325.

20. Beezhold DH, Pugh B, Liss G, Sussman GL. Correlation of protein levels with skin prick reactions in latex allergic patients. J Allergy Clin Immunol. 1996;98(6):1097-1102.

21. Yunginger JW, Jones RT, Fansway AF, Kelso JM, Warner MA, Hunt L. Extractable latex allergens and proteins in disposable medical gloves and other rubber products. J Allergy Clin Immunol. 1994;93(5):836-842.
22. Cornish K, Brichta JL, Yu Pauline, Wood DF, McGlothlin MW, Martin JA. Guayule latex provides a solution for the critical demands of the non-allergenic medical products market. Agro-Food-Industry Hi-tech. 2001;12:27-31.

23. Baur X. Are we closer to developing threshold limit values for allergens in the workplace? Ann Allergy Asthma Immunol. 2003;90(5):11-18.

24. Seyfarth F, Schliemann S, Wiegand C, Hipler UC, Elsner P. Diagnostic value of the ISAC( $($ ) allergy chip in detecting latex sensitizations. Int Arch Occup Environ Health. 2014;87(7):775-781. 